\title{
Enhancing the Educational Activities of Law Students as One of the Ways to Improve Efficiency and Quality of the Professional Training
}

\author{
Marina S. Nebeska ${ }^{1}$, Yevheniia M. Provorova ${ }^{2}$, Elvira M. Gerasymova ${ }^{3}$, Zorina S. Vykhovanets ${ }^{4} \&$ Pylyp S. \\ Yepryntsev $^{5}$ \\ ${ }^{1}$ Department of State Law Disciplines, Odessa State University of Internal Affairs, Odessa, Ukraine \\ ${ }^{2}$ Department of Theory and Methods of Voice Staging, Faculty of Arts, National Pedagogical Dragomanov University, \\ Kyiv, Ukraine \\ ${ }^{3}$ Department of Social Philosophy, Philosophy of Education and Educational Policy, Faculty of Management of \\ Education and Science, National Pedagogical Dragomanov University, Kyiv, Ukraine \\ ${ }^{4}$ Department of Foreign Languages, National Pirogov Memorial Medical University, Vinnytsya, Ukraine \\ ${ }^{5}$ Faculty No. 4, Donetsk Law Institute of the Ministry of Internal Affairs of Ukraine, Kryvyi Rih, Ukraine \\ Correspondence: Yevheniia M. Provorova, Department of Theory and Methods of Voice Staging, Faculty of Arts, \\ National Pedagogical Dragomanov University, 9, Pyrogova str., Kyiv, 01601, Ukraine.
}

Received: May 13, 2020

doi:10.5430/ijhe.v9n4p291
Accepted: June 24, 2020

Online Published: June 26, 2020

\begin{abstract}
The article urges the problem of enhancing the academic activity of law students as one of the ways of improving the efficiency and quality of professional training. The nature and structure of academic activity of future lawyers are covered. Thus, academic activity is a form of a human activity, which structure is viewed through the prism of mastering a set of knowledge and methods of activity, moral and ethical values, as well as social relations. Academic activity of student youth promotes mastering of basic methods and practical experience of solving professional problems, development of planetary thinking and creativity, that is, it is a professional-oriented activity. In order to enhance the academic activity of law students, the features of its structure were investigated. In particular, the following components were selected: motivational, cognitive and practical.

A questionnaire on the topic "Why did I choose the profession of a lawyer?" was conducted. The pedagogical experiment and psychological research based on two methodologies, Ilyina's "Motivation to study in higher educational institutions" and Ayzenko's method of figurative thinking "Find regularity", have been involved.

An assessment of the impact done by interactive teaching methods of students, who are studying at the National Aviation University, the specialty "Law", has also been provided.

The main ways to solve the problem of intensifying the educational activities of future lawyers have been identified. They include the development of communication, mental processes, motivation to study, active involvement of students in educational activities, and taking responsibility for studying in the higher educational establishment. Problems of interaction between teachers and students while training and increasing students' independence need further development.
\end{abstract}

Keywords: academic activity, interactive technologies, professional training, enhancing, motivation, creativity, independent work

\section{Introduction}

Today's globalization processes establish new requirements and rules of the professional training of lawyers in higher educational institutions. Ukrainian education should build an educational process in such a way that it allows future lawyers to acquire integrative knowledge, skills and abilities to implement them successfully in their future activities. Nevertheless, innovative pedagogical methods and forms of teaching will not contribute to the positive dynamics of the learning activities of lawyers unless they are actively involved in the process, and their actions will not be motivated; moreover, a clear goal should be set. Therefore, enhancing students' academic activity is one of the main aspects of improving the efficiency and quality of professional training (Ponomareva, 2014). 
Research into the complex support for enhancing academic activity, which combines the basic principles, factors, directions and conditions for improving student activity, is urgent and needs detailed study. There are drawbacks in modern higher education, namely: the monotony of the use of traditional forms, methods in teaching, which leads to a decreased interest in learning and loss of motivation to study (Shepelenko, 2017).

The objective of the article is to intensify educational activities of law students as one of the ways to increase the efficiency and quality of professional training.

The results of the study allowed to formulate a research hypothesis, the essence of which was that effective and high-quality professional training of law students is possible provided the intensification of educational activities.

\section{Materials and Methods}

The psychological and pedagogical study was of a prolonged character and covered three interrelated stages. The first stage is analytical and introductory (2016-2017). It was devoted to the analysis of theoretical sources of the research; study of scientific and pedagogical, philosophical, and pedagogical literature; theoretical and conceptual understanding of the problem; defining the aim, main tasks, and hypotheses; and choosing the necessary research methods.

The second stage is diagnostic and search (2017-2018). It involved conducting an experiment and forming a hypothesis.

The third stage is conceptual modeling (2018-2019). It had research and experimental orientation, namely: based on the data of theoretical analysis and the results of the experiment, the activation of educational activities of law students was characterized as one of the ways to improve the efficiency and quality of their training. In addition, conclusions and recommendations for the implementation of the results of the study in the practice of higher education were justified.

The experiment involved 137 students of the 1-5 year who are studying at the National Aviation University, the specialty 081 "Law."

The following research methods were used in the study to analyze the activation of the educational activities of the student youth:

- theoretical analysis, synthesis, comparison, and matching - for the conceptualization of philosophical and psychological-pedagogical scientific literature, the study of legal documents in the field of education; classification and systematization of theoretical and experimental data concerning the activation essence of law students' educational activity, comparative analysis of theoretical and experimental data obtained as a result of the application of research methods, and modeling of educational activity of students;

- observational (pedagogical observation and self-analysis) method; diagnostic methods (various types of surveys, questionnaires) - to determine the attitude of future legal professionals to the chosen profession and to study the motivation for learning and mental processes of law students; psychological methods - "Motivation to study in higher educational establishments" by Ilyina (see Semichenko (2004)); Ayzenko's method of figurative thinking "Find regularity" (see Bekh (2008)); testing - to diagnose the cognitive component of the activation of educational activities of legal professionals, a control test to monitor academic achievements of students majoring in "Law" was conducted on the basis of the Center for Independent Testing of the Department of Pedagogy and Psychology of Vocational Education.

\section{Results}

A lawyer is a specialist in law, legal sciences; a legal practitioner. As noted in the scientific literature, a lawyer is a professional who has specialized legal knowledge and is aware that the most important features are law and legality for society, expertly uses his professional knowledge, skills and abilities to solve legal problems in order to protect rights and interests of citizens.

Describing the job of a lawyer, attention should be paid to substantiating the content of his/her professional activity, which consists of the general features of the profession and the basic rules, standards and requirements that the profession of lawyer establishes for the individual (Slyvka, 2000).

The main components of a job description of a lawyer include the approaches that help to solve professional problems, namely: communicative is characterized by the following features: emotional stability; ability to express their opinions and respect to the client; social includes such quality as fairness, organizational - responsibility, commitment, organizational abilities. Therefore, the academic activity of future lawyers is directed to the 
development of these personal and professional qualities.

Learning is a vital activity for humanity in which motivation plays a key role. Naturally, learning motivation may vary depending on the type of learning. However, this work focuses on virtual modalities or e-learning.

According to foreign literature, there are different types of motivation, depending on the number and level of control. Internal motivation is the archetype of autonomy, and external motivation is related to the variables they govern. There are four types of external motivation: (1) external regulation; (2) introduced regulation in which the individual internalizes emergencies; (3) determined regulation in which the individual recognizes the importance of the activity; and (4) complex regulation in which the individual behaves in harmony with his needs. This model is comparable to other student learning models (Deci \& Ryan, 2008; 2014; Nuñez \& León, 2015; Vermunt \& Donche, 2017).

Academic activity is a form of human activity, which structure is viewed through the prism of mastering a set of knowledge and methods of activity, moral and ethical values, as well as social relations. Academic activity of student youth promotes mastering of basic methods and practical experience of solving professional problems, formation of planetary thinking and creativity, that is, it is a profession-oriented activity.

A student is the object of pedagogical activity in the academic process. Moreover, the main purpose of pedagogical activity in higher educational institutions is the formation of personality and professional qualities, the development of intellectual abilities, awareness of themselves as a subject of educational activity. The object of the student's educational activity is the assimilation of scientific theoretical and practical material. The products of his activity are answers (demonstration of knowledge, skills, abilities), which are evaluated at examinations and tests.

Thus, a future legal practitioner, as a subject of educational and professional activity, has his/her own goal, own methods for achieving it and personal ability. One of the main tasks for teaching staff at all levels of professional training is to help future law students find their life path and place in life (Artiushyna, 2013).

The role of educators is essential for enhancing student learning. Success depends on the behaviour of teaching staff, which contributes to the creative activation of student youth and their belief in the effectiveness of the educational process (Shahvand \& Rezvani, 2017). Encouraging learning behaviours include curriculum structure, teaching methods, assessment of learning, and the organization of a positive team climate (Shahvand \& Rezvani, 2017).

When the teacher organizes influence on the object, (s)he should take into account the fact that the student never develops in direct dependence of the pedagogical influence on him, but according to his laws, peculiar psychological characteristics, namely perception, memory, thinking, will, character, formation of professional abilities. The student becomes the subject of academic activity under the influence of education. It is the pedagogical staff in higher educational institutions who should help the student to become an active subject of academic and professional activity, which underlies the essence of self-development of the individual (Ivankiv, 2018).

Success depends greatly on the type of motivation of each student: competent teacher assistance and how effective and interesting learning strategies are (Firat, Kılınç \& Yüzer, 2018). There are, however, some variables that can be optimized, such as the extension of a type of activity so that they can challenge all learning styles (Segura \& Greener, 2014).

The activity of students is their immersion in the subject of activity: the willingness to complete assignments, the desire to learn independently, use all the necessary information from scientific sources, and increase their intellectual potential.

The activity should be seen in two different but interrelated aspects: an activity as an expression of cognition in a particular learning situation and an activity as a quality of personality of social importance. They are interdependent. Only a certain attitude of a student to the academic activity, which is formed depending on the situation in the learning process, contributes to the gradual transformation of this attitude into a stable feature that characterizes the quality of an individual. This transformation is characterized by complications of the motivational sphere, the level of independence and consciousness of an individual.

On this basis, enhancing of learning should be understood as the teacher's mobilization of the intellectual, volitional and physical forces of students in order to achieve the set goals in the academic activity. That is, enhancing of learning is the process and result of stimulating student activity in the process of learning.

The activity of law students at all stages of the educational activity depends on enhancing the educational process in general, and the educational process depends directly on the personality of a teacher and his/her professional qualities to organize the academic activity. Most students find the activity interesting and interactive when teachers request active student involvement in the natural environment (Huang, Backman, Backman, MacGuire \& Moore, 
2019).

In order to enhance the academic activity of law students, it is important to explore the features of its structure (components: motivational, cognitive, and practical). Cognitive component is characterized by thinking and mental ability. This component consists of the following stages: mastery of knowledge, which depends on the professional competence of teachers, as well as consolidation and use of the acquired knowledge (Dmytruk, 2014).

The motivational component is characterized by the general orientation of student youth on educational activity; positive attitude to learning. This component provides a purposeful attitude towards self-education activities. The motivation in law students is developed in the appropriate interaction of a teacher with student youth: the use of interactive teaching methods, namely game, creative assignments that help to activate the independent activity of the future lawyer. The practical component of educational activity is characterized by such features as curiosity and self-improvement. It directs the future lawyer to self-development, self-education, self-examination and observation of his own professional actions. It is the independent work that helps to form this component. In the process of organizing the educational process, teachers clearly identify the skills that a student should have in the process of independent work, namely: use the guide, summarize, analyse, determine the main points in the material provided, etc. Independent work is done without the participation of teachers, but they organize it and guide the student. Therefore, independent work is an active student's activity which directs him to achieve the desired goal and the didactic goal set by the teacher. The effectiveness of learning that underlies any research depends on how the teacher evaluates his effectiveness in the learning process, includes belief in himself and his ability to create successful academic activity (Shohoudi, Zandi, Faridi, Fathi \& Safari, 2015). Thus, the interaction of these three components is the foundation for the professional development of a future lawyer.

At the National Aviation University, special pedagogical techniques and methods were used in the educational process with law students in order to enhance the academic activity. Diagnosis was performed to identify the level of particular indicators.

Today, one of the most common types of surveys is questionnaires. The respondent fills in a questionnaire by him/herself. Thus, ensuring complete anonymity and confidentiality.

A questionnaire is a replicated document that includes a set of questions formulated and related to each other according to the established rules. Due to the fact that the questionnaire is filled in by the respondent by him/herself, its composition, a place of questions, language and style of their formulation are especially important.

In order to study the motivational component of enhancing the educational activity of future lawyers, the questionnaire "Why did I choose the profession of a lawyer?" and the Ilina's method "Motivation for Studying at Higher Educational Institution" were used. The results of the study are presented in Table 1.

Table 1. Results of law students based on the questionnaire "Why did I choose the profession of a lawyer?"

\begin{tabular}{|c|c|c|c|c|}
\hline Item & Question & Answer options, \% & & \\
\hline 1. & $\begin{array}{l}\text { Why did I choose } \\
\text { the profession of a } \\
\text { lawyer? }\end{array}$ & $\begin{array}{l}75 \% \text { - parents influenced } \\
\text { the choice }\end{array}$ & $\begin{array}{l}25 \% \text { chose this } \\
\text { profession on their } \\
\text { own }\end{array}$ & - \\
\hline 2. & $\begin{array}{l}\text { Why is this } \\
\text { profession better } \\
\text { than others are? }\end{array}$ & $\begin{array}{l}36 \% \text { - the profession of a } \\
\text { lawyer is currently } \\
\text { prestigious }\end{array}$ & $\begin{array}{l}\text { for } 58 \% \text { of students } \\
\text { the main thing is } \\
\text { high salary }\end{array}$ & $\begin{array}{l}7 \% \text { of respondents said } \\
\text { that this speciality had the } \\
\text { advantage of social } \\
\text { importance of the } \\
\text { profession }\end{array}$ \\
\hline 3. & $\begin{array}{l}\text { How will the } \\
\text { profession of a } \\
\text { lawyer help you in } \\
\text { the life? }\end{array}$ & $\begin{array}{l}38 \% \text { of students regard the } \\
\text { chosen profession as the } \\
\text { opportunity to build a } \\
\text { successful career }\end{array}$ & $\begin{array}{l}40 \% \text { of respondents } \\
\text { said that the } \\
\text { profession was } \\
\text { simply prestigious } \\
\text { in a modern society }\end{array}$ & $\begin{array}{l}22 \% \text { of students said that } \\
\text { the profession of a lawyer } \\
\text { would help them to find } \\
\text { themselves and promote } \\
\text { self-improvement }\end{array}$ \\
\hline
\end{tabular}

Motivation is one of the factors that determine the development of creative activity of an individual. Some researchers believe that creativity requires motivation for achievements; others believe that motivation for social approval blocks the creative process, complicates the manifestation of creative abilities of an individual. Most authors are convinced that the motivation and personal enthusiasm is the main feature of a creative personality. 
However, the existing studies provide no consensus on how to measure this indicator in the process of teaching creativity. For example, foreign scholars in their empirical studies have measured the impact of creative work on creativity and thinking (Ritter \& Mostert, 2016), creative production (Byrge \& Tang, 2015), and self-assessment of creativity.

In our study, Ilyina's "Motivation to study in higher educational institutions" was used to study the influence of the motivation of law students to studying in a higher educational institution. The results of the study are shown in Figure 1.

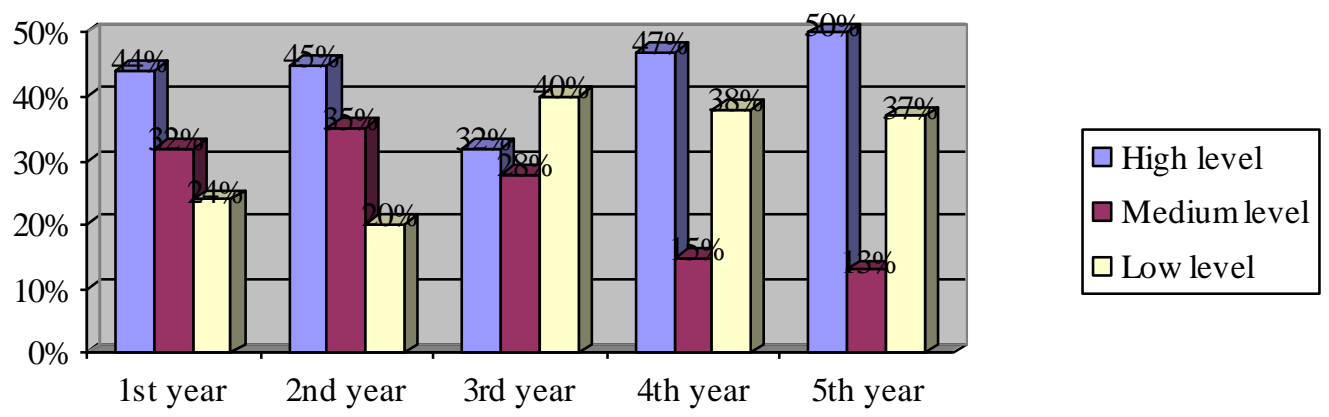

Figure 1. Motivation for studying (\%)

As we can see from the data obtained, $62 \%$ of students have a high level of motivation for studying, but in the $3^{\text {rd }}$ year the number of students with a high level of motivation dropped sharply to $25 \%$. We can hypothetically assume that at the $3^{\text {rd }}$ year of study the students get disappointed with their educational activities and choice of a profession. Starting from the $4^{\text {th }}$ year, it gradually levelled off, thus indicating a more developed motivation of future lawyers for learning.

Motivation for professional activity was also considered. The results of the study are shown in Figure 2.

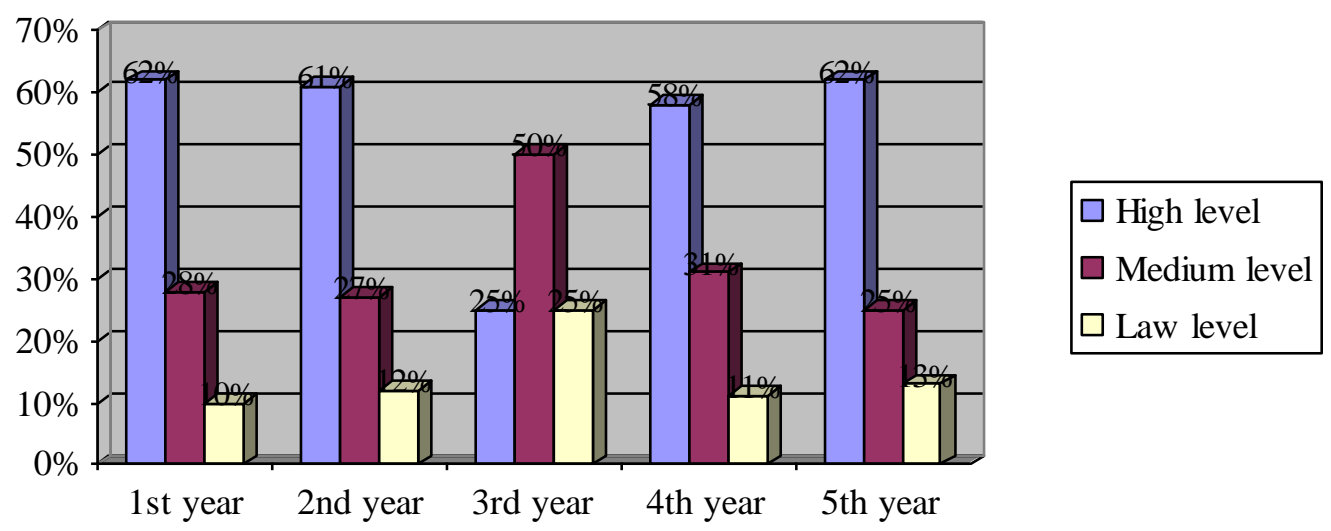

Figure 2. Motivation for professional activity (\%)

As we can see from the data obtained, $44 \%$ of $1^{\text {st }}$ year students have a high level of motivation for professional activity, during the $3^{\text {rd }}$ year the number of students with a high level has decreased sharply and amounted to $32 \%$. It can be hypothetically argued that during this year of study the students get disappointed with their future professional activities.

Based on the analysis of the results of the "Motivation for Studying in Higher Educational Institution" method, it is found that the majority of students studying in the higher educational institution, the speciality "Law," seek only a diploma of higher education, but are not willing to develop skills for mastering professional activities.

Investigating the cognitive component of enhancing the academic activity of future lawyers, we have chosen thinking as a process of cognitive activity of a person, characterized by a generalized and indirect reflection of the 
outer world and internal experiences. To assess thinking, we used Ayzenko's method of figurative thinking "Find regularity." The dynamics of the level of thinking of future lawyers is shown in Figure 3.
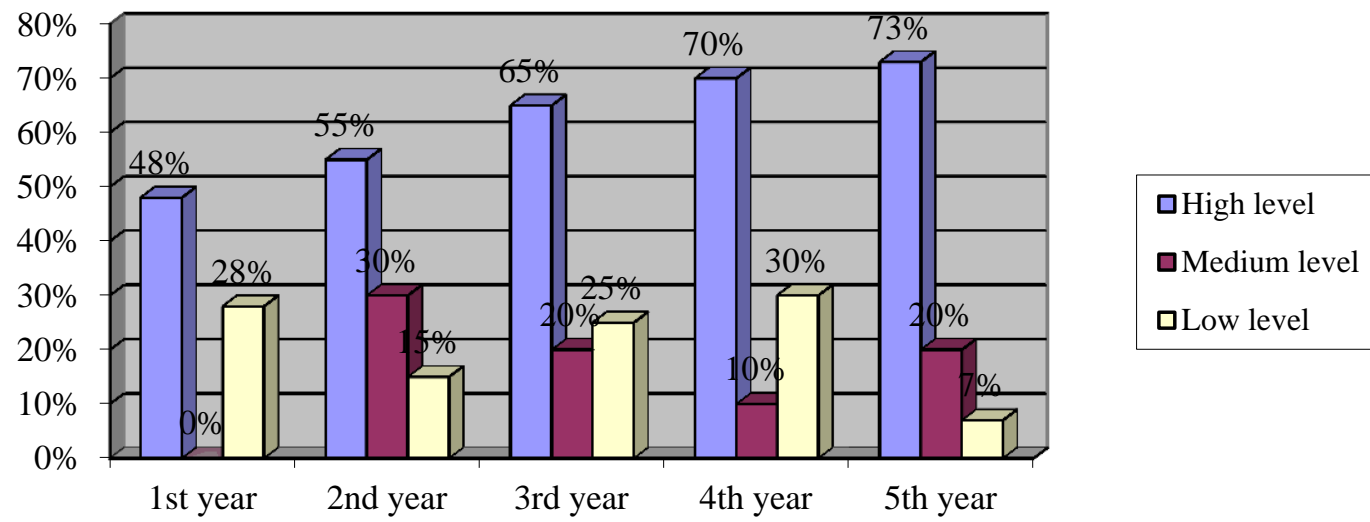

Figure 3. Dynamics of the future lawyers' level of thinking (\%)

The purpose of the development of thinking is to adapt to new conditions at the behavioural level and to solve new problems. The processes of thinking in the educational system are reduced to: 1) general ideas and concepts; 2) judgments and conclusions.

The study found that from the $1^{\text {st }}$ to the $5^{\text {th }}$ year the number of students with high levels of thinking is increasing (among students of the $5^{\text {th }}$ year $72 \%$ have high levels of thinking, $8 \%$ have low levels). In general, as we can see, the difference between the years of study in terms of the levels of thinking is insignificant. On this basis, we can conclude that a comprehensive system of professional training has insufficient influence on the formation of thinking of law students in the learning process and requires more attention.

In addition, to diagnose the cognitive component of the activation of the educational activity of lawyers, a control test of academic performance of law students was conducted at the Center for Independent Testing of the Department of Pedagogy and Psychology of Professional Education. Nowadays, a recognized objective form of knowledge control is computer-based testing, which provides mass rapid diagnostics of knowledge, its impartiality, reliability, objectivity and transparency. At the same time, the introduction of the computer-based testing system into the training of future lawyers, the creation of fairly objective and technological tests is a many-sided and time consuming process, its result depends on the joint efforts of teachers and specialists in the field of information and communication technologies that directly create pedagogical educational software, including computer-based tests developed by teachers.

The control test is an integrated work that included assignments from different subjects. Standard assignments were used at the first stage of the experiment, which allowed future lawyers to show their professional knowledge obtained during the study of specialized subjects. At the next stage, law students completed tasks that required the involvement of thinking and creative abilities. During the third stage, students were offered specific professional problem situations to test students' knowledge, skills and ability to make the right decisions to solve these problems, explaining why they think so. Each indicator was characterized by the following levels: low, medium and high. The results of the study are presented in Table 2.

Table 2. Results of pedagogical research of students of the $1^{\text {st }}-5^{\text {th }}$ years of study

\begin{tabular}{|c|c|c|c|}
\hline Indicators & Low level & Medium level & High level \\
\hline 1. Integrative knowledge and professional skills & $16 \%$ & $26 \%$ & $58 \%$ \\
\hline 2. The ability of law students to think critically and logically & $25 \%$ & $29 \%$ & $46 \%$ \\
\hline $\begin{array}{l}\text { 3. Ability to independently explain legal issues on the basis of } \\
\text { theoretical knowledge acquired }\end{array}$ & $24 \%$ & $25 \%$ & $51 \%$ \\
\hline $\begin{array}{l}\text { 4. Ability to summarize, evaluate and apply familiar information to } \\
\text { master new knowledge and skills, draw conclusions and make } \\
\text { forecasts }\end{array}$ & $21 \%$ & $30 \%$ & $49 \%$ \\
\hline
\end{tabular}


According to the results of the study, all the figures in the majority of students had a high level, which indicates that in the course of academic activities the students have acquired the professional knowledge and skills that are required in their future activities.

However, because classes are generally understood to be a broad construct that encompasses audience involvement, as well as the use of support systems such as professor working hours or additional courses (Fredricks, Filsecker \& Lawson, 2016; Sinatra, Heddy \& Lombardi, 2015) these studies are unlikely to offer any conclusions about the learning process itself. Moreover, visible participation of student youth occurs in small groups as it gives more opportunities for students to engage in learning (for example, by doing exercise).

Analysing Loveland's (2014) study, who divided the introductory Statistics course at the university level into two sections for two semesters - one section was taught entirely in the traditional lecture style, the other involved active teaching methods, and the other section was characterized by the use of a minimum number of lectures. Analysing student examination scores and their views, Loveland (2014) found no significant difference in the results. Activity-based teaching did not lead to better understanding of students or improvement of professional skills, nor did it lead to more positive student attitudes.

The students' comments indicated a positive response to activity-oriented methods, but also to the need to have more time to focus on the teacher.

However, in contrast to these findings, a number of studies identified the benefits of traditional approaches to teaching and learning. In trying to show that student-centered learning environments encourage a deep learning approach, for example, Baeten, Struyven and Dochy (2013) compared a student-centered lecture environment.

The purpose of the practical component was the formation and improvement of methods of organizing independent activity, the use of various innovative methods and forms of independent work. Educational literature and methodological recommendations for ensuring independent work of law students were of great importance. All this contributes to the development of self-control and self-improvement in future lawyers.

Encouraging students to become independent and active is achieved through problematic search for material rather than "ready knowledge". The problem-seeking method of providing information directs students to independent search for information, independent conclusions, generalizations. This, in turn, contributes to the development of the student's personality, his self-consciousness, self-esteem. A favourable moral and psychological atmosphere of the educational process is the ability to apply dialogue in the educational process. It is dialogue that is an effective method of enhancing student learning, as evidenced by the following indicators: openness of expression and students' confidence in the teacher; free, confident behaviour of students during classes; lack of fear of possible mistakes; applying to teacher for help if necessary; the absence of any barriers to the exchange of ideas regarding the solutions to the educational assignments.

In the modern world high school pedagogy, students' independent work is considered as a leading form of professional training of future specialists.

It is in the process of independent work that a law student himself becomes the creator of his knowledge. It promotes a positive attitude to his profession, develops capacity to work, forms a critical assessment of his abilities, take responsibility for decisions, strive for achieving positive results.

Independent work of law students should be based on the creation of appropriate psychological and pedagogical conditions, appropriate management (for example, the volume of material, types of assignments, methodological recommendations for their completion), which helps to improve the quality of academic activity. The success of learning depends on interest and positive motives. An important influence on the independent work of the law student is the orientation, psychological readiness, as well as the appropriate level of knowledge to which the acquired knowledge will be overlapped (Shepelenko T. 2017).

With regard to the development and achievement of independence, some scholars believe that it allows developing new skills. Independence is associated with a tendency for motivation, which is the main requirement for positive results (Deci \& Ryan, 2008; Kazantseva, Valiakhmetova, Minisheva, Anokhina \& Latypova, 2016).

Thus, qualitative and quantitative changes have occurred among law students of the National Aviation University through the introduction of interactive methods.

As an example, they analysed the scientific research of foreign scholars, who evaluated three criteria in the course of the experiment - ultimate interest of students, subjective achievement in learning and formation of academic competences, as well as mediating - cognitive involvement - at the end of the semester in the final survey. A six-item 
cognitive involvement scale was developed to cover the cognitive aspects of behavioural belonging (Jang, Kim \& Reeve, 2016), focusing on students' attentiveness during sessions and enhancing their learning activities. Thus, the study confirms the positive results of the use of methods of working with law students, proving that a significant factor in improving the quality of professional training of students for professional activity is the enhancement of academic activity.

In the learning process, the selection of teaching methods that direct the student to successful results is of great importance. In doing so, the student must be able to use knowledge, abilities and skills, to apply them in practical activities, to develop, etc., as the level of effectiveness of educational activity depends directly on the level of intensive academic activity of a student.

At the same time, when using different methods and enhancement techniques, it is always necessary to take into account the existing level of development of cognitive abilities of students.

Students who have a high level of intellectual abilities can offer challenging tasks, and those who have a low level of development do not feel any positive dynamics of an academic activity.

Thus, the activitiy formation of law students, improving the quality of academic activity, which is focused on mastering professional and practical experience, ensuring the adaptation/disadaptation of personality to the environment, assisting in self-development and promoting professional development of a specialist are the main purpose of enhancement.

\section{Discussion}

Today, there are different ways to enhance academic activity of law students, namely learning forms, methods, tools, their corresponding combination and application for successful learning, ensuring active involvement and independence of students.

We state that the law students' academic activity is largely enhanced through interactive teaching methods, independent work and the problem-seeking method of teaching and learning (Bondareva, 2013).

In many European countries, teaching methods of enhancing the law students' involvement are being promoted at high school. For example, the German Council of Science and Humanities called on university students to be active partners of teachers in the educational process, rather than passive participants. These recommendations are supported by significant financial incentives. For 2011-2020, the Federal Ministry of Education and Research has invested two billion euros to improve student support and quality of teaching at high school. This exemplary national policy is linked to the efforts in higher education at the European level. Promoting student-centered learning was a clear goal of the Bologna Process during the conference held in Leuven in February 2009. In the Bucharest Communiqué (EHEA, 2009), ministers reiterated their commitment to "promote student-centered higher education, characterized by innovative teaching methods that engage students as active participants in their learning".

Methods of enhancing educational and cognitive activity turn learning into creative search activity, which positively influences its effectiveness, motivates to the search for various methods of learning. These days, the necessity of enhancing law students' educational activity is because the assignments are effectively completed with the help of interactive methods, which cannot be solved with the help of traditional learning techniques (Artiushyna, 2013).

Enhancing learning activities of law students using interactive methods provides for modelling of life situations, the introduction of business games, trainings, discussions - all this will contribute to the formation of professional skills, vital values, the creation of a friendly atmosphere and communication.

Student enhancement methods have led to greater engagement and much better learning than traditional lectures. Freeman et al. (2014) conducted a meta-analysis with the study STEM subjects and presented strong evidence of the benefits of activating learning parameters over traditional lectures: the scores were higher and activity levels were much lower than in traditional ones.

Considering interactive learning as an innovative pedagogical phenomenon, it is necessary to justify its importance in the educational process.

The methods of interactive learning for law students in modern pedagogical activity include: heuristic conversation, method of discussion, brainstorming, method of business game, training, case studies, etc. The main advantage of interactive teaching methods is the use the energy of group interaction, the mobilization of all sensory organs without exception, intuition and other personal and professional qualities by students in learning.

During the research, a number of methods of interactive technologies were used: game modelling method; method of 
cases and practical situations; method of psychological training.

Let us consider the implementation of each of the above mentioned methods in details.

Game modelling method helps to accumulate and update professional knowledge, skills and competences, taking into account personal experience, increasing interest in learning and promotes intense cognitive activity in the synthesis of legal knowledge; develops the flexibility of professional thinking; forms a creative approach to making problematic decisions.

Brainstorming is a business game where some practical problem is solved through collective thinking. This method stimulates thinking of law students when they express their thoughts, in addition there is an exchange of views of other participants. The main purpose of this method is to activate creativity in the process of group discussion of ideas and formation of new ones.

The professional skills are improved through using the case method and the method of practical situations: the study of life situations when one of the components of the problem is the behaviour of different population groups; presentation and interpretation of situations concerning future professional interests; search and use of theoretical knowledge in a dynamic situation; development of an algorithm of actions, making particular decisions; application of theoretical knowledge, concepts and established techniques in specific situations. Thus, the use of the case method in the educational process should ensure the optimal combination of theoretical learning and practical skills, which is especially important for future lawyers.

The method of psychological training is characterized as a means of reprogramming the model of behaviour and management of activity that already exists in humans; in addition, the training process focuses on the development of personality as a whole.

In the teaching process of law students the following exercises were used: "Knowing yourself" - it helps students to deepen into their inner world, to identify deviations in knowledge and skills, to form interpersonal communication; "Mediation Features" - develops the participants' dialogical communication skills, generates the ability to handle conflict situations; "Effective Communication" - promotes the development of communicative abilities, building confidence, favourable moral and psychological climate in the team; "Solve Problem Situations" - helps to find the main ways of solving controversial issues, and the participants' readiness to solve problematic situations; "Modelling Cognitive Tasks" - promotes the activation of creative potential when solving professional cognitive tasks; "Theatricalization" - acting out an episode on a training topic, for example, students are asked to play a court trial of a case, while a judge, plaintiff, defendant, witnesses and other participants in the proceedings are selected; this exercise help determine the originality of resolving the situation, the degree of justification, knowledge of current legislation, acting skills. Through these exercises, the teacher can observe the student's interest and willingness to participate in educational games.

Therefore, the classes of law students should be based on the principle of cooperation. This principle involves focusing on gaining positive moral and psychological experiences by the students in the process of joint activity. The success of any main course depends not only on the teacher's experience, but also on his ability to teach creativity, which can be achieved through the advanced training of teaching staff (Göksu, 2017). Creativity, thinking processes of students can be improved through effective academic activity (Azevedo, Morais \& Martins, 2017).

\section{Conclusion}

Therefore, analysing the results of psychological and pedagogical study, it can be stated that only a comprehensive organization of academic activity, including all aspects of the process of education in higher educational institutions aims at clear identification of the main ways to achieve the set goal. And, of course, the teachers' pedagogical skills, based on a high level of his professional competence, are of great importance.

The outputs of the study, the intensification of the learning process is the mobilization of intellectual, volitional, and physical strengths of students by a teacher to achieve goals in the learning process. Thus, the intensification of learning is a process and result of stimulating student activity in educational activities.

The proposed solutions to the problem of enhancing academic activity of future lawyers were characterized by a high level of motivation, intellectual abilities, communication, and active involvement of students in the academic activity and independent work, accepting responsibility for the academic performance. The problems of interaction between teachers and students in the educational process and increasing the independence of students in the process of professional training of future lawyers require further improvement. 


\section{Acknowlegements}

We express our gratitude to all the participants and colleagues who contributed to this study.

\section{References}

Artiushyna, M. V. (2013). Methods and Procedures of Students' Motivation and Stimulation of the Educational Activity. Zhytomyr Ivan Franko State University Journal, 3, 25-32.

Azevedo, I., Morais, M., \& Martins, F. (2019). The future problem solving program international: an intervention to promote creative skills in Portuguese adolescents. Journal of Creative Behaviour, 53(3), 263-273. http://doi.org/10.1002/jocb.175

Baeten, M., Struyven, K., \& Dochy, F. (2013). Student-centered teaching methods: can they optimise students' approaches to learning in professional higher education? Studies in Educational Evaluation, 39, 14-22. https://doi.org/10.1016/j.stueduc.2012.11.001

Bekh, I. D. (2008). Education of personality: textbook. Kyiv: Lybid.

Bondareva, T. (2013). Activation of educational and cognitive activity of students in the system of higher education. New pedagogical thought, 1, 83-85.

Byrge, C., \& Tang, C. (2015). Embodied creativity training: effects on creative self-efficacy and creative production. Thinking Skills and Creativity, 16, 51-61. https://doi.org/10.1016/j.tsc.2015.01.002

Deci, E. L., \& Ryan, R. M. (2008). Facilitating optimal motivation and psychological well-being across life's domains. $\quad$ Canadian Psychology/Psychologie $\quad$ Canadienne, $49(1), \quad$ 14-23. https://doi.org/10.1037/0708-5591.49.1.14

Deci, E. L., \& Ryan, R. M. (2014) Motivation, personality, and development within embedded social contexts: an overview of self-determination theory. In R. Ryan (Ed.), The Oxford Handbook of Human Motivation, 85-107. New York, NY: Oxford University Press.

Dmytruk, L. A. (2014). Theoretical and methodological principles of integration of educational-cognitive and self-educational activity of students of higher educational institutions ( $\mathrm{PhD}$ dissertation). Institute of Pedagogy of the National Academy of Pedagogical Sciences of Ukraine, Kyiv, Ukraine.

EHEA. (2009). The Bologna Process 2020: The European Higher Education Area in the new decade. Retrieved from http://media.ehea.info/file/2009_Leuven_Louvain-la-Neuve/06/1/Leuven_Louvain-la-Neuve_Communique_Ap ril_2009_595061.pdf

Firat, M., Kılınç, H., \& Yüzer, T. V. (2018). Level intrinsic motivation of distance education students in e-learning environment. Journal of Computer Assisted Learning, 34(1), 63-70. https://doi.org/10.1111/jcal.12214

Fredricks, J. A., Filsecker, M., \& Lawson, M. A. (2016). Student engagement, context and adjustment: Addressing definitional, measurement, and methodological issues. Learning and Instruction, 43, 1-4. https://doi.org/10.1016/j.learninstruc.2016.02.002

Freeman, S., Eddy, S. L., McDonough, M., Smith, M. K., Okoroafor, N., Jordt, H., \& Wenderoth, M. P. (2014). Active learning increases student performance in science, engineering, and mathematics. Proceedings of the National Academy of Sciences of the United States of America (PNAS), 111(23), 8410-8415. https://doi.org/10.1073/pnas.1319030111

Göksu, G. (2017). Being creative for teaching creativity: teachers' and instructors' self-assessments regarding creativity. Journal of Faculty of Educational Sciences, 50(2), 225-253.

Huang, Y.-C., Backman, S., Backman, K., MacGuire, F., \& Moore, D. (2019). An investigation of motivation and experience in virtual learning environments: a self-determination theory. Education and Information Technologies, 24(1), 591-611. https://doi.org/10.1007/s10639-018-9784-5

Ivankiv, I. B. (Ed.). (2018). Condition of legal education in Ukraine. Analytical research based on the results of educational measurements. Kyiv: Waite.

Jang, H., Kim, E. J., \& Reeve, J. (2016). Why students become more engaged or more disengaged during the semester: A self-determination theory dual-process model. Learning and Instruction, 43, 27-38. https://doi.org/10.1016/j.learninstruc.2016.01.002

Kazantseva, E. A., Valiakhmetova, E. K., Minisheva, L.V., Anokhina, S. Z., \& Latypova, E. M. (2016). A 
survey-based study of motivation and attitude to learning a second language at UFA State University of Economics and Service. Global Media Journal, S2, 1-9.

Loveland, J. L. (2014). Traditional lecture versus an activity approach for teaching statistics: A comparison of outcomes (Doctoral dissertation). Utah State University, Logan, Utah. Retrieved from http://digitalcommons.usu.edu/cgi/viewcontent.cgi?article=3089\&context=etd.

Nuñez, J., \& León, J. (2015). Autonomy support in the classroom. A review from Self-Determination Theory. European Psychologist, 20(4), 275-283. https://doi.org/10.1027/1016-9040/a000234

Ponomareva, H. F. (2014). The interaction of a teacher and a student in pedagogical higher educational establishment teaching and educational process. Problems of Engineering and Pedagogical Education, 45, 25-36.

Ritter, S., \& Mostert, N. (2016). Enhancement of creative thinking skills using a cognitive-based creativity training. Journal of Cognitive Enhancement, 1(3), 243-253. https://doi.org/10.1007/s41465-016-0002-3

Segura, B., \& Greener, S. (2014). Technology on CALL: improving English language learning in a Spanish context. In R. Ørngreen, \& K. T. Levinsen (Eds.), Proceedings of the 13th European Conference on e $\square$ Learning ECEL $\square 2014$, 464-469. Copenhagen: Curran Associates, Inc.

Semichenko, V. A. (2004). Problems of motivation of behavior and human activity. Modular Psychology Course. Module "Directivity". Kiev: Millennium, 2004.

Shahvand, M., \& Rezvani, E. (2017). Iranian EFL teachers' beliefs and practices on effective teaching: the case of gender and level of experience. Research in English Language Pedagogy, 3(2), 30-43.

Shepelenko, T. L. (2017). Theoretical aspects of the issue of students' cognitive activity and independence. Bulletin of Alfred Nobel University. Series "Pedagogy and Psychology", 2(14), 109-115. https://doi.org/10.32342/2522-41-5-2017-0-14-109-115

Shohoudi, M., Zandi, K., Faridi, M., Fathi, G., \& Safari, Z. (2015). Relationship of teaching efficiency with academic self-efficacy and self-directed learning among English language students: university students' perspectives. Educational Research in Medical Sciences, 4(2), 68-77.

Sinatra, G. M., Heddy, B. C., \& Lombardi, D. (2015). The Challenges of Defining and Measuring Student $\begin{array}{lllll}\text { Engagement in } & \text { Science. }\end{array}$ https://doi.org/10.1080/00461520.2014.1002924

Slyvka, S. (2000). Legal deontology: problems, searches. Law of Ukraine, 11, 118-122.

Vermunt, J. D., \& Donche, V. (2017). A learning patterns perspective on student learning in higher education: state of the art and moving forward. Educational Psychology Review, 29, 269-299. https://doi.org/10.1007/s10648-017-9414-6 